\title{
Revised lithostratigraphy of the Mesozoic-Cenozoic succession of the onshore Rovuma
}

\section{Basin, northern coastal Mozambique}

Key, R M. ${ }^{\mathrm{a}}$, Smith, R A ${ }^{\mathrm{a}}$, Smelror, M. ${ }^{\mathrm{b}}$, Powell, J H. ${ }^{\mathrm{d}}$, Thorsnes, T. ${ }^{\mathrm{b}}$, Njange, F ${ }^{\mathrm{c}}$, Sæther, O.M. ${ }^{\mathrm{b}}$ and Zandamela, E B. ${ }^{\mathrm{c}}$

${ }^{a}$ British Geological Survey, Murchison House, West Mains Road, Edinburgh EH9 3LA, U.K.

${ }^{\mathrm{b} G e o l o g i c a l ~ S u r v e y ~ o f ~ N o r w a y, ~ L e i v ~ E i r i k s s o n s ~ v e i ~ 39, ~ T r o n d h e i m ~ N O-7491, ~ N o r w a y ~}$

'Direcção National de Geologia, PO Box 217, Pemba, Mozambique

${ }^{\mathrm{d} B r i t i s h}$ Geological Survey, Keyworth, Nottingham NG12 5GG, U.K.

Keywords: Lithostratigraphy, Mesozoic-Cenozoic formations, Rovuma Basin, Mozambique

\begin{abstract}
A revised formal lithostratigraphy for the Mesozoic-Cenozoic succession of the onshore portion of the Rovuma Basin in northern Mozambique replaces a previous mixture of informal lithostratigraphical and biostratigraphical names. The new lithostratigraphy is based on fieldwork carried out in 2005 by mapping teams from the Geological Survey of Norway (NGU), British Geological Survey (BGS) and the Mozambique Direcção National de Geologia (DNG) ${ }^{1}$, combined with information taken from published papers and maps, and unpublished reports at the DNG made available to the project. The following formations are formally described: Rio Mecole Formation (Jurassic? age), N'Gapa Formation (Jurassic? age), Pemba Formation (late Jurassic and early Cretaceous age), Macomia Formation (AptianAlbian age), Mifume Formation (Albian (offshore)/Campanian (onshore)-Maastrichtian age), Alto Jingone Formation (Paleocene-Eocene age), Quissanga Formation (middle Eocene to Oligocene age), Chinda Formation (Neogene age) and Mikindani Formation (Neogene age). The thickest accumulation of sediments occurred during the Cretaceous concomitant with intense erosion of the uplifted African interior. The Basin's geology records the temporal development of the coastline of northern Mozambique and southern Tanzania over the last 200 or so million years. Throughout this period, intermittent, mostly extensional faulting parallel to the approximately N-S to NNW-SSE coastline strongly influenced sedimentation, and the faults remain active along this 'passive' continental margin. These faults cut across the ENE-WSW structural grain of the underlying Precambrian crystalline rocks of the East African Orogen. However, transfer faults identified in the offshore part of the Rovuma Basin are parallel to the Precambrian structural grain, and may well represent reactivated major ductile shear zones, e.g. in the area between Pemba and Quissanga.
\end{abstract}

\footnotetext{
${ }^{1}$ ) As a part of a Nordic Development Fund (NDF)-World Bank-funded regional mapping project of Mozambique.
} 


\section{Introduction}

The NNW-SSE trending Rovuma Basin, a southern part of the extensive East Africa passive margin basin system, extends for about $400 \mathrm{~km}$ from southern Tanzania as far south as Nacala (Hancox et al., 2002; Smelror et al., 2006a, Fig. 1). In northern Mozambique the basin has a maximum E-W width of about $160 \mathrm{~km}$ where it covers an area of about $17000 \mathrm{~km}^{2}$ onshore with a further $12500 \mathrm{~km}^{2}$ offshore (Flores, 1973; Hancox et al., 2002). Its onshore part either unconformably overlies Precambrian metamorphic and igneous rocks of the East African Orogen, or is in fault contact with these crystalline rocks (Figs. 2 and 3). The maximum thickness of sediments in the entire Rovuma Basin is about $10 \mathrm{~km}$ based on geophysical surveys (Lonropet SARL, 2000). Kent et al. (1971) also show a thickness of about $10 \mathrm{~km}$ in an E-W section in southernmost Tanzania that includes a basal faulted basin infilled by Karoo strata. A single deep borehole (Mocimboa-1) sited close to the present coastline of northern Mozambique penetrated through $3490 \mathrm{~m}$ of the upper part of the Rovuma Basin sequence before terminating in Aptian-Albian marls (Salman and Abdula, 1995). However, the succession thins rapidly westwards so that the westernmost onshore part of the Basin is probably much less than $1000 \mathrm{~m}$ in northern Mozambique.

The entire stratigraphical development of the Rovuma Basin is directly related to the progressive break-up of south-western Gondwana that created Africa as a separate continent. Intra-continental tectonism (regional crustal uplift and associated faulting) associated with the East Africa Rift System also influenced Cenozoic sedimentation in the Rovuma Basin. Rift basins aligned along, or close to the suture line of the subsequent break up of the Gondwana Supercontinent now marked by Africa's eastern coastline first developed within the supercontinent between about 200 and 165 Ma BP (Reeves et al., 2002, Reeves, 2003; Jelsma et al., 2004). Sediments deposited in such rifts are preserved in the basal parts of the Rovuma Basin, presently offshore, as well as along its western onshore margin. Salman and Abdula (1995) refer to these sediments as the 'Syn-Rift' (Triassic to lower Jurassic) tectonostratigraphical mega-sequence. These rift-basins are not aligned with, and locally cut across, the older rift-basins of eastern Africa infilled by Karoo strata.

Dextral strike-slip movement along the Davie Fracture Zone at about 165 Ma BP marked the start of continental drift with the opening of a south-facing gulf south off what is now northern Tanzania (Reeves et al., 2002, Reeves, 2003). Progressive opening of this gulf and of a north-facing gulf along what is now the coast of NE Africa eventually caused, at about 135 Ma BP, the complete separation of eastern Africa from the rest of eastern Gondwana. Salman and Abdula (1995) refer to sediments deposited in the Rovuma Basin during the middle Jurassic to lower Cretaceous period of continental break-up as the 'Early Drift' tectono- 
stratigraphical mega-sequence, and for younger (post- 135 Ma) Aptian-Oligocene sediments as the 'Late Drift' tectono-stratigraphical mega-sequence. A major period of sedimentation into the Rovuma Basin occurred during the Cretaceous to coincide with intense erosion of the uplifted interior of Africa (Tinker, 2005; Kounov et al., 2007 de Wit, 2007). Cenozoic (Oligocene to Recent) sedimentation into the Rovuma Basin is dominated by the growth of an eastern thickening wedge of deltaic sediments offshore from the Rovuma River- the 'Deltaic Progradation’ mega-sequence of Salman and Abdula (1995).

Nicholas and co-workers (Nicholas et al. 2006, 2007; Pearson et al., 2004, 2006) provide detailed descriptions of the upper Cretaceous-Paleogene stratigraphy, sedimentology and tectonic setting of the Rovuma Basin of the coastal zone of southern Tanzania based on their studies over the last decade. They note that a passive margin developed along coastal Kenya and Tanzania in mid-Cretaceous times (to coincide with the split of Madagascar from India and the opening of the Mascarene Basin at about $93 \mathrm{Ma}$ ) and persisted until the early Miocene (Kent et al., 1971; Collins, 2003; Nicholas et al., 2006). The sedimentary sequences that accumulated on the passive margin between the late Cretaceous and early Oligocene are referred to the Kilwa Group (Nicholas et al., 2006; Pearson et al., 2004, 2006). They also present evidence for compressional tectonics during the more recent period of offshore sedimentation.

Previous works on the Rovuma Basin of northern Mozambique include those of Bornhardt (1900), Flores (1973), Daniels et al. (1977), Civitelli (1988), Afonsky et al. (1990), Salman and Abdula (1995) and Hancox et al. (2002). They describe a number of litho- and biostratigraphic units throughout the basin. However, many of these units are informal with no consensus on their nomenclature. Here we propose a new and unified formal lithostratigraphic scheme for the onshore Rovuma Basin in Northern Mozambique (Fig. 4). The proposed lithostratigraphy is based on: (1) fieldwork carried out in 2005 by mapping teams from the Geological Survey of Norway, British Geological Survey and the Mozambique Direcção National de Geologia (DNG) as a part of the geological mapping component of the World Bank/NDF-funded Mineral Resources Management Capacity Building Project for the Ministry of Mineral Resources and Energy, Government of Mozambique, and, (2) information from published papers and unpublished reports made available to the project. The new stratigraphic nomenclature uses local place names in northern Mozambique and southern Tanzania as the formal names of the revised lithostratigraphic units (formations).

Fig. 2 shows the distribution of the mapped formations with the oldest two sedimentary units (N'Gapa Formation and Rio Mecole Formation) preserved in small isolated, fault-controlled (NNW-SSE) basins located along the western limit of the Rovuma Basin. Table 1 shows the 
relationships between the recently defined formations within the Kilwa Group of southern Tanzania (Nicholas et al., 2006) and the new formations of northern Mozambique. The changing tectonic setting of the southern part of the Rovuma Basin during the evolution of the Mozambique Channel is illustrated in Table 2 (modified from Lonropet SARL, 2000).

\section{Details of the revised lithostratigraphy}

This section formally defines the formations recognised in the Mozambique onshore sector of the Rovuma Basin. Appropriate place names in northern Mozambique or southern Tanzania (Mikindani) are used to name formations.

\section{Rio Mecole Formation}

Name: Named after the small river Rio Mecole.

Type section: Exposures along the main road from Mueda to Pemba at UTM 62708549 (Fig. $5 a)$.

Reference section: Basal conglomerates exposed near UTM 6240898560758 (Fig. 5b).

Thickness: The exact thickness of the formation has not been determined, but only locally exceeds $100 \mathrm{~m}$.

Distribution: The formation is preserved in a narrow NNW-SSE graben that is about $30 \mathrm{~km}$ in total length situated about $40 \mathrm{~km}$ west of Pemba and immediately west of the faulted western margin of the Rovuma Basin (Fig. 2).

Lithology: The Rio Mecole Formation comprises continental, reddened coarse siliciclastic sedimentary rocks with the westernmost strata dipping at moderate angles to the NW and NE.. Basal clast-supported breccias consist of metre-sized blocks in a sandy matrix. Locally derived banded migmatitic gneisses and amphibolites are the dominant clast lithologies. Sandy beds, partly pebbly, occur infrequently. These pass up to matrix-supported conglomerates interbedded with coarse-grained to pebbly, thickly bedded sandstones and redbrown micaceous siltstones. The conglomerates comprise angular granitic, amphibolitic and gneissic clasts up to about $15 \mathrm{~cm}$ in length supported in an arkosic (granitic) matrix. The sandstones are cross-bedded with bimodal sets and may have carbonate cement. Sequences locally fine upwards (Moura, 1974).

Basal boundary: Excellent exposures of a basal breccia occur near UTM 6240898560758 at the western boundary of the sedimentary rocks (Fig. 5b). The actual contact with underlying 
metamorphic and granitic crystalline rocks is not exposed, but the breccia outcrops less than $10 \mathrm{~m}$ laterally from gneiss exposures without any escarpment.

Age: No age-diagnostic fossils have been found in the continental coarse clastics of the Rio Mecole Formation, but the few recovered palynomorphs point towards an undefined ?Jurassic age (Smelror et al., 2006b; Smelror et al, in press). It is possible that the continental sediments of the Rio Mecole (and N'Gapa) Formation are laterally equivalent to the marine sandstones, siltstones and mudstones of the lower Pemba Formation deposited during the Late Jurassic transgression, although they are now only preserved in isolated rifts or sub-basins.

Depositional environment: The formation comprises high-energy fluviatile sediments deposited in small, intra-continental rift-basins. Uplifted Precambrian rocks adjacent to the rifts provided proximal source areas. Cross-bed foresets of the sandstones exposed along the main road from Mueda to Pemba (UTM 6270 8549) indicate palaeoflows to the NW and NE. Therefore sediment was transported into the rift-basins by river systems off both shoulders of the NNW-trending rift.

Remarks: In the first description of this unit, Moura (1974) suggested it was either Jurassic to Cretaceous in age, or part of the Karoo Supergroup. It appears to be of similar age to the N'Gapa Formation.

\section{N'Gapa Formation}

Name: Named after the village of N’Gapa.

Type section: Exposure on hill west of N'Gapa (at UTM 531864 8750230).

Reference section: Exposure north of N’Gapa (UTM 532760 8751140).

Thickness: The thickness of the formation is not known exactly, but it is in the order of $100 \mathrm{~m}$ in the N'Gapa area.

Distribution: The N'Gapa Formation occurs as seven small outliers and half-grabens with the largest outcrop area at N'Gapa (Fig. 2).

Lithology: The formation comprises conglomerates and well cemented, buff to purplish, moderately sorted, medium to coarse-grained and pebbly sandstone, which is locally crossbedded (Fig. 6). The pebbles are mainly of white vein quartz, $0.5-3 \mathrm{~cm}$ long, and the larger rounded clasts are concentrated at the bases of channels. Other common clasts include dark grey chert and kaolinitic mudstone. On top of the hill west of N'Gapa, bedded units, about 1 
$\mathrm{m}$ thick, include scattered pebbles up to $10 \mathrm{~cm}$ long, in coarsening upwards units with weak near horizontal bedding towards the top.

North of N'Gapa (UTM 532760 8751140) the typical pinkish purple and buff- yellow mottled sandstones are well cemented, quartz-rich, and coarse-grained to pebbly with a silicified kaolinitic matrix. These sandstones fine upwards from pebbly bases into planar and crossbedded units. Cross-bedding indicates that palaeocurrents generally flowed to the west.

Basal boundary: The basal boundary is exposed in the type area where a buff, purple and red sandstone and conglomerate succession unconformably overlies Precambrian gneisses.

Age: The formation is considered to be of Jurassic age and possibly comprises late Jurassic sediments (see comments on the age of the Rio Mecole Formation). It is older than Aptian as it either passes up into the base of the Macomia Formation or lies unconformably below that formation (Smelror et al., 2006b).

Depositional environment: The poorly sorted nature of these strata is interpreted as due to deposition of the original sediments in alluvial fans or on scree slopes within, or on the shoulders of intra-continental rift basins. The presence of fining up in channels among the poorly sorted reddened sandstones with evidence for strong kaolinisation suggests fluviatile reworking of the sediments in a warm, humid climate.

Remarks: On the previous geological maps of the Rovuma Basin, the terrestrial clastic beds near N'Gapa have been referred to as either Karoo Supergroup or Jurassic in age. No fossils have been found which could confirm the age of the N'Gapa Formation. The rocks are lithologically different from, and therefore interpreted as younger than Karoo Supergroup rocks exposed farther west in Niassa Province. N'Gapa Formation strata could be a proximal basal facies of the Macomia Formation, but they have distinctly kaolinised character, which has been taken as a sign of the very humid, warm environment that prevailed prior to earliest Cretaceous times (when the climate was hot and dry). Therefore the N'Gapa Formation strata are inferred to predate the Early Cretaceous and could be late Jurassic in age. Pinna and Marteau (1987) noted that the lowermost sandstones west of N'Gapa are more strongly fractured than the overlying sandstones (of the Macomia Formation), which would also suggest that a period of brittle deformation separated deposition of the two formations.

\section{Macomia Formation}

Name: Named after the village Macomia. It was first described as a series of sandstones exposed in southern Tanzania, and referred to as the Makonde Beds (Bornhardt, 1900; Flores 
and Noseda 1961). The sandstones from the Macomia area were also referred to as the Maconde Formation (Hancox et al., 2002).

Type section: A cliff section about 20 km south of Namatil (UTM 549028 8746190)

Reference section: A 100m high cliff just north of Nangade (UTM 573136 8775873).

Thickness: The thickness of the Macomia Formation generally varies between 80 and $300 \mathrm{~m}$. However, around Mueda the formation is estimated to be up to $500 \mathrm{~m}$ thick.

Distribution: The formation forms the plateau extending east and south of Mueda and north towards the Rio Rovuma (Fig. 2). However, a veneer of Mikindani Formation covers the plateau so that exposure of the Macomia Formation is confined to a western escarpment.

Lithology: The Macomia Formation comprises mainly coarse to fine-grained quartzofeldspathic or arkosic sandstones with local conglomeratic beds (Figs. 7a\&b) resting on Precambrian gneisses. The cement varies from calcareous to siliceous to kaolinitic. The kaolin is partly derived from in situ weathering of feldspar. Multi-storey sequences of trough cross-bedded sandstone in sets $30 \mathrm{~cm}-1 \mathrm{~m}$ thick are common (Fig. 7c). Less common planar sets tend to be bimodal.

Northern exposures of the formation comprise fining upwards sequences. Cliffs beside the river valleys in the northern part of the Mueda plateau (including the type section) provide good exposures of up to $100 \mathrm{~m}$ vertical section. A basal $15 \mathrm{~m}$ of interbedded white quartzrich, poorly silica-cemented sandstone and pink-weathered siltstone is overlain by finegrained pale grey sandstone capped by $45 \mathrm{~m}$ of fining upwards thickly bedded (2-5 m) medium-grained sandstones including thinly laminated sandstone intervals. The reference section in the cliff north of Nangade, and $30 \mathrm{~km}$ to the SSW, comprises up to $70 \mathrm{~m}$ of finegrained pink-white arkosic sandstone with scattered round quartz pebbles; overlain by basal conglomerate of the Mikindani Formation. The upper part of the Macomia Formation here is fine-grained, thinly laminated and trough cross-bedded with thin heavy mineral seams (Fig. $7 a)$.

Exposures from central parts of the formation's outcrop also show fining-upwards sequences. The escarpments extending south from Mueda towards Macomia (Fig. 2) are typically made up of a succession of buff to reddish, coarse-grained to pebbly sandstones with conglomeratic and clast-supported microconglomerate interbeds. Interbedded conglomerates tend to be impersistent and poorly sorted, up to $2 \mathrm{~m}$ thick and infill channels with a sharp base. Most of the pebbles are up to $5 \mathrm{~cm}$ in length, but exceptionally 6 to $20 \mathrm{~cm}$ long including pinkish 
kaolinitic silty mudstone cobbles. The majority of the clasts are quartz with subordinate Kfeldspar (some coarse enough to be derived from pegmatite), sandstone, quartzite, mylonite, chert and kaolinitic silty mudstone. A ravine section east of Mueda (UTM 588294 8700092) passes up from thick bedded, off-white and pink, medium- and coarse-grained sandstones with conglomeratic lenses in trough cross-bedded sets, into a $2 \mathrm{~m}$ thick interval of red to purple mudstone with a green mottled palaeosol at its top. The overlying fine-grained, rippled sandstones are succeeded by red-brown medium-grained sandstones. In general argillaceous interbeds, such as a buff yellow siltstone $0.8 \mathrm{~m}$ thick, east of Madava, are sparse.

Southern exposures are dominated by coarse-grained arenaceous deposits. The well exposed escarpments near Muage (UTM 623456 8635734) of over 150 m of coarse-grained to pebbly sandstones have been described by Hancox et al. (2002). These occur in multi-storey units over $10 \mathrm{~m}$ thick and pebble lags lie at the bases of the channels. The Macomia Formation also forms the hill to the SW of Macomia (UTM 622277 8645266) where arkosic sandstones contain reddish to pink detrital feldspars as well as pinkish fine-grained sandstone clasts. Pebbly to conglomeratic sandstones with large scale cross-beds and parallel laminated units indicating upper flow regime fluvial deposition. In the escarpment west of Macomia, multistorey, cross-bedded sandstones (0.4 - 2 m thick) include some near horizontal planar-bedded units over $1.2 \mathrm{~m}$ thick, which are bimodal in grain size. Local thicker sandstone interbeds contain cobbles and boulders of reddish medium- to coarse-grained sandstone up to $2 \mathrm{~m}$ in length (Fig. 7b). These massive beds may have been deposited by debris flows.

Eastern (and therefore stratigraphically higher) exposures comprise more common finer grained lithologies relative to the western escarpments. In roadcuts between Mueda and Mocimboa da Praia sandstones are commonly friable in mottled red, white, yellow or purplebrown units fining up into thin silty mudstones. Larger lenses of reddened kaolinitic mudstone, siltstone and fine-grained sandstone are probably the argillaceous infill of channels. Channel bars of trough cross-bedded, coarse-grained to pebbly sandstones with pebble lags at bases of beds are interbedded with medium-grained, well sorted and well cemented purplish grey and white mottled sandstones. The trough cross-bedding indicates palaeoflow to the NW and E. In the roadcut at (UTM 588217 8719800) the trough crossbedded sandstones are interpreted to have palaeoflows to the NE, ESE and SSW as a result of deposition in braided river channels. South-east of Macomia (UTM 629368 8634504), dark grey micaceous siltstones and black organic rich mudstones are locally interlaminated and dip gently SW. 
Basal boundary: The base of the formation generally comprises conglomeratic beds resting on Precambrian gneisses. However, in places such as south of N'Gapa, the Macomia Formation appears to overlie the N'Gapa Formation.

Age: The Macomia Formation contains well preserved assemblages of terrestrial and marine palynomporphs providing evidence of an Aptian-Albian age of the formation (Hancox et al., 2002; Smelror et al., in press). Aitken (1960) accepted an Aptian age for this unit in southern Tanzania.

Depositional environment: The Macomia Formation is interpreted as a predominantly high energy, reworked proximal fluviatile sequence deposited in a braided channel system. The overall palaeoflow was to the east (confirming the western and south-western source area deduced by Hancox et al., 2002) from a proximal source of underlying Precambrian rocks. The organic-rich mudstones seen to the SE of Macomia are interpreted as lacustrine to lagoonal in origin. There is little evidence of marine facies apart from sparse bioturbation and the sparse foraminifera recovered by Hancox et al. (2002) from the formation. However, In Tanzania the equivalent formation has intercalated marine limestone beds of Aptian age. Extensive kaolinisation of the detrital feldspars and the presence of the kaolinitic mudstone clasts suggest that the palaeoclimate was hot and humid.

Remarks: Renewed rifting in the Rovuma Basin and active erosion and deposition onshore created the fluvio-deltaic Macomia Formation during an Aptian marine transgression that deposited Pemba Formation sediments to the east (Fig. 4). The presence of a lagoonal facies with a marine influence low down in the east of the Macomia Formation's outcrop compared to the western escarpment where only fluvial facies have been observed, suggests that the active braided river facies were situated to the west and prograded eastwards over the lagoonal facies. Bioturbated units near Macomia interpreted as marine incursions (Hancox et al., 2002) were not recorded in the western escarpment, either because there was no marine influence or the equivalent units were eroded prior to the deposition of the overlying Mikindani Formation. Interbedded debris flows within the Macomia Formation are considered to be the result of instability in the basin as it continued rifting. At roughly the same time in the southern part of the Pemba Formation outcrop, a turbiditic facies appears to have been rapidly deposited at the foot of the delta.

\section{Pemba Formation}

Name: Named after the city Pemba. It has previously been called the "Megatrigonia schwartzi Beds" and Aptian-Albian sandstones and marls (Flores, 1960) and the 'Marine Lower 
Cretaceous beds' (Flores and Noseda, 1961). Civitelli (1988) used the terms, lower Cretaceous "Conglomerates and sandstones" and "Belemnite bearing sandstones and marls" for Pemba Formation deposits.

Type section: North of Pemba Bay (Flores and Noseda, 1961).

Reference section: Near Mecufi at UTM 6598768541325.

Thickness: It is impossible to accurately estimate the thickness of this laterally extensive formation due to the very low dips (eastwards) that vary from horizontal up to about $15^{\circ}$ (except next to faults where beds can steepen up to about $25^{\circ}$ ) and the flat topography. However, the formation thickens eastwards and is at least several thousand metres thick in the offshore part of the basin based on the interpretation of geophysical data (Lonropet SARL, 2000).

Distribution: The Pemba Formation outcrop in the Mecufi area underlies the whole of the western part of the Rovuma Basin. The onshore outcrop width of the Pemba Formation decreases southwards from about $20 \mathrm{~km}$ to about $10 \mathrm{~km}$ in the southernmost part of the mapped area. This formation is generally well exposed, either in numerous stream and river sections or as low rock exposures.

Lithology: The Pemba Formation consists of sandstone, siltstone and mudstone. The content of carbonate cement is commonly high, and in some places the formation includes limestone beds (Fig. 8a). A tripartite internal lithostratigraphy is recognised between the Rio Lurio and Pemba with a basal (western) unit of sandstones and conglomerates interbedded with mudstones and limestones, a middle coarsening-upwards unit of flaggy, well-bedded sandstones, followed an uppermost (eastern) turbiditic unit of interbedded sandstones, mudstones and siltstones.

The basal unit comprises well cemented as well as strongly compacted, buff-coloured, fine to coarse-grained feldspathic sandstones with detrital mica (biotite and muscovite) flakes as well as quartz and feldspar. Grey mudstones and fine-grained limestone interbeds are present in the sandstones with individual beds up to $1.5 \mathrm{~m}$ in thickness. Belemnites as well as worm and crab burrows are locally preserved (Fig. 8b). Ripple marks, convoluted bedding (Fig. 8c), low angle planar cross bedding and trough cross bedding and desiccation cracks are also preserved. Individual sandstone beds fine upwards from conglomeratic bases to cross-bedded sandstone tops. Unconformable contacts with underlying gneisses are exposed at UTM 6467428516670 and at UTM 6464528516584 and at several locations to the west of here (e.g. at UTM 646246 8516647). This would imply an undulating contact with Pemba 
Formation conglomerates deposited in natural hollows in the underlying gneiss surface that may or may not be locally fault controlled. The western conglomerates comprise rounded vein quartz pebbles, angular granitic clasts up to boulder size and angular siltstone clasts in a coarse-grained arkosic matrix with sandstone interbeds.

The middle unit is made up of a coarsening-upwards sequence of flaggy feldspathic sandstones in beds between $10 \mathrm{~cm}$ and $1 \mathrm{~m}$ in thickness. The sandstones are commonly laminated and locally conglomeratic. Detrital mica and less common garnet occur in the sandstones. Belemnites, shell fragments and worm burrows are locally preserved as well as circular cavities and mounds on weathered surfaces that are up to $1 \mathrm{~m}$ in diameter. This unit appears to disappear south of the Rio Lurio where the turbiditic sequence directly overlies the basal sandstones and conglomerates.

The upper unit comprises a fining-upwards turbiditic sequence of fissile, thinly bedded sandstones, siltstones and mudstones and less common conglomerates (Fig. 8d). Individual siltstone beds are graded (Fig. 8e) with fine-grained sandstone bases. The sandstones are mostly feldspathic and contain detrital muscovite flakes, traces of black organic material with clay and/or carbonate cement. The conglomerates and pebble beds contain granitic and gneiss pebbles as well as vein quartz pebbles and mudstone flakes. Imbricated pebbles indicate palaeocurrents directed towards $060^{\circ}$. Convoluted bedding, flute casts, desiccation cracks, ripple drift cross-laminations and cross bedding are commonly observed. Worm and crab burrows are common and there are isolated belemnite fossils. Some sandstone beds are composed entirely of quartz (e.g. at UTM 659774 8497419). Bed forms are typically wavy. An uppermost part of the turbiditic sequence is characterized by discrete ridges of thickly bedded sandstones exposed south of the Rio Lurio. These sandstones commonly contain detrital muscovite.

Inland and north of Pemba, the three-fold division of the formation has not been established due to poor exposure. Buff weathered, medium-grained, well sorted and bioturbated or shelly sandstones are common. Other lithologies include banded and interlaminated mudstones and siltstones, pebble conglomerates, buff-grey to off-white, shelly bioclastic limestone (Fig. 8a) and coarse-grained and partly sparry calcite-cemented limestone beds. For example, east of Muage, the formation varies from a sequence of pale grey to red mottled, medium to coarsegrained sandstones with clay-filled burrows and rare shell fragments (UTM 6314068617432 ) to yellowish buff, medium-grained, trough cross-bedded sandstones (UTM 642048 8612818). The sandstones contain scattered olive-grey mudclasts and locally quartz granules to pebbles. East of Bilibiza an interbed of small pebble conglomerate is up to $1.5 \mathrm{~m}$ thick (UTM 640027 8611032). Some of the coarser clastic beds contain quartz, feldspar, kaolinitic mudstone and 
lithic clasts of similar provenance to the Macomia Formation. These interbeds may in part be similar in age and facies to the Macomia Formation (e.g. at UTM 6332628616754 ) but because of the association with the marine facies, these beds are all mapped as Pemba Formation. Pale and dark grey interlaminated mudstone and silty mudstone are exposed in the road south of Mahate (UTM 654315 8605248) below thin bedded, hard, iron oxide cemented fine-grained sandstones, and some of these beds contain iron-oxide rich rounded concretions (UTM 654338 8604490).

Basal boundary: Unconformable, as well as faulted contacts with Precambrian rocks are exposed along the western margin of the basin.

Age: The oldest unit of the Pemba Formation is dated as Kimmeridgian-Tithonian based on the marine microfloras found in the unit (Smelror et al., in press). Younger parts of the formation are dated as Barremian to Aptian based on the recovery of abundant age-diagnostic beleminites, bivalves, pollen, spores and dinoflagellate cysts (Flores \& Noseda, 1961; Civitelli 1988; Smelror et al., in press). The turbiditic sandstones contain common reworked Barremian dinoflagellate cysts. The onshore boundary between the Pemba Formation and the overlying Mifume Formation is unconformable and appears to be markedly diachronous. The exposed contact between the two formations is locally angular, separating gently eastwarddipping Pemba Formation strata from flat-lying Mifume Formation strata. In other places, both formations are subhorizontal and the unconformity is marked by a change in lithology.

Depositional environment: The formation represents a coastal progradation into an open marine environment (i.e. deltaic to shallow shelf settings). Previously, Flores and Noseda (1961) inferred a deltaic environment and noted more abundant fault-controlled sedimentation south of Pemba towards the Lurio River exposures. Moura (1974) and Mariani et al. (1984) interpreted the western sequence of variably cross-bedded, carbonate-cemented arkosic sandstones with conglomerates lenses as fluviodeltaic in origin. The basal unit is made up of proximal sediments sourced from adjacent granitic rocks and deposited in a marine environment as (shown by the presence of belemnites). Rapid, shallow marine deposition of the rest of the formation is shown by the abundance of soft sediment deformation structures and the preservation of mud cracks, ripple drift and other sedimentary structures. The middle, coarsening up unit of the Pemba Formation can be interpreted as a deltaic to open marine succession, probably continuing up into Barremian times. The clastic component continued to have a strong continental signature. Coarse-grained and partly sparry calcite cemented limestone beds seen north of Pemba probably formed bioherms in a shallow marine environment. 
Remarks: The lower unit has previously been mapped as part of the Macomia Formation. It is now regarded as part of the Pemba Formation because of the presence of marine fauna. Sedimentation was contemporaneous with the maximum period of erosion in southern Africa (de Wit, 2007). The very pronounced linear western margin of the Rovuma Basin indicates that it is controlled by a NNW-trending fault. It is possible that the bounding fault formed a scarp feature during sedimentation of the Pemba Formation that originally lay to the east of the present margin of the basin. Subsequent erosion of the fault escarpment led to westward retreat of this escarpment with eroded material covering the trace of the primary fault.

\section{Mifume Formation}

Name: The formation is named after a small village near Pemba. It was previously known as the Globotruncana marls or Globotruncana Formation (Flores and Noseda, 1961).

Type section: West side of the Pemba Peninsula at UTM 6648698554534.

Reference section: Exposure in a gully at UTM 6645098565632 in Pemba.

Thickness: This formation is about 200 m thick west of Pemba (Flores and Noseda, 1961) and thickens eastwards to about $810 \mathrm{~m}$ in the Mocimboa-1 Borehole.

Distribution: The Mifume Formation underlies a N-S ridge between Mecufi and Pemba, and is patchy exposed along the same trend north to Quissanga (Fig. 2).

Lithology: Grey marls or mudstones and calcareous sandstones (locally with detrital garnet and mudstone flakes) are the main lithologies and limestones were also intersected in the Mocimboa-1 Borehole. The marls are strongly bioturbated and preserve worm burrows (Fig. 9). Interbedded sandstones are up to about $70 \mathrm{~cm}$ in thickness and they coarsen upwards in a section from UTM 6598768541325 (base) to 664476 85444866. Internal laminations define trough cross beds.

A distinctive succession of olive-grey to pale grey calcareous mudstones or marls is exposed in the type section. At its base near UTM 664869 8554534, pale grey-brown calcareous mudstones are interbedded with fine-grained well-cemented and burrowed sandstone beds 1-3 $\mathrm{cm}$ thick. In the reference section there are 2-3 m of weakly bedded marls cut by thin fibrous gypsum veins and fractures coated with brown iron oxides. Underlying pale grey shaly marl is locally silty. In nearby cliffs, paler grey fine-grained sandy siltstone about $1 \mathrm{~m}$ thick is interbedded with grey marl. Near the top of the cliffs, the marl succession is unconformably overlain by red-brown and white burrowed pebbly sandstone belonging to the Mikindani Formation. 
At UTM 6496488664952 south of the Mucojo road, the exposure of over $1.5 \mathrm{~m}$ of weathered olive-green to yellow-brown mottled silty mudstone with minor fine-grained pale grey-green sandstone interbeds is considered to belong to this formation unconformably below about a metre of poorly sorted pebble conglomerate at the base of pink-brown sandstones belonging to the Mikindani Formation.

Basal boundary: The lower boundary of the Mifume Formation is exposed at UTM 659876 8541325 and defined by the lower surface of the lowest marl bed.

Age: Civitelli (1988) suggested a Middle Campanian to Middle Maastrichtian age for the Mifume Formation based on the age-diagnostic foraminifera species Globotruncana arca, Globotruncana ventricosa and Globotruncana falsostuarti. Marine microflora recovered in samples from outcrops at Pemba Bay confirm a Late Campanian age at this locality (Smelror et al., in press). However, the log of the Mocimboa-1 Borehole indicates that the Mifume Formation spans the whole of the upper Cretaceous (Cenomanian to Maastrichtian). It is possible that the Mocimboa-1 Borehole sequence is a more distal, open marine facies to include limestones with continuous deposition throughout the upper Cretaceous and the attenuated sequences reflect a more confined period of sedimentation following a period of non-deposition when the westernmost part of the basin remained above sea level.

Depositional environment: The formation was deposited in an open marine shelf environment above a diachronous unconformity on top of the Pemba Formation. There is a west to east facies change from western near-shore sediments to eastern open sea sediments concomitant with an eastward thickening of the Formation. Upper limestones that are well exposed along the present coast are confined to eastern parts of the formation. There is an intra-upper Cretaceous unconformity recognised in the thicker, eastern part of the formation.

Remarks: Sedimentation was contemporaneous with extensive inland erosion that fed the sandstone interbeds common in western exposures of the formation. Open distal marine deposition of muddy carbonates belonging to the Mifume Formation continued (Mocimboa-1 Borehole) from Cenomanian to Maastrichtian times but its lateral equivalent near Pemba is a near-shore sandy facies deposited during the Campanian-Maastrichtian period.

\section{Alto Jingone Formation}

Name: The Alto Jingone Formation is named after the outcrop area immediately south of Pemba (Fig. 2) first described by Flores and Noseda (1961) and referred to as the QuissiruaRepa Formation by Moura (1974). It is Paleocene in age and corresponds to the "Fossiliferous marls" of Civitelli (1988). 
Type section: Quarry west of Pemba at UTM 6645058565688.

Reference section: West of Pemba at UTM 6638528565328.

Thickness: The formation is typically between 50-100 m thick in the Pemba area. A thickness of about $135 \mathrm{~m}$ is recorded in the Mocimboa-1 Borehole.

Distribution: The formation is patchily exposed in the southern half of the outcrop area of the Rovuma Basin (Fig. 2).

Lithology: The formation comprises interbedded bioclastic and variably sandy and locally gypsiferous sparry limestones (Fig. 10a), calcareous siltstones, marls and mudstones and variably bioturbated calcareous sandstones. Shell and other fossil fragments, calcareous nodules, mudstone clasts (Fig. 10b), foraminifera including Nummulites were observed in these rocks as well as variably oriented, sand filled worm tubes (Fig. 10c). Beds are up to $1 \mathrm{~m}$ in thickness but commonly much thinner and are subhorizontal or dip gently to the NNE. Local faulting has steepened bedding with westerly dips and there are calcite veins locally..

A small quarry in the type section exposes up to $2 \mathrm{~m}$ of off-white, bioclastic sparry to micritic limestone forming irregular nodules up to $30 \mathrm{~cm}$ across in an olive-green mudstone matrix. Carious weathered limestones, in beds c. $15-40 \mathrm{~cm}$ thick form cliffs in the reference section. These beds dip gently to the WSW and comprise scattered calcareous pebbles and bioclasts in a fine-grained sparry calcite matrix. Coral colonies and clasts are characteristic and small quartz and sparry white limestone clasts are also present. Echinoid spines, shark teeth and oysters are common in the bioclastic limestones.

A southern outcrop can be traced for about $20 \mathrm{~km}$ through the village of Simuco where massive limestones and sandstones are exposed. The limestones are conglomeratic with clasts of coral, shell fragments and rounded quartz pebbles in calcite cement (Fig. 10d). There are also coral reefs that locally form coastal cliffs up to $10 \mathrm{~m}$ in height (e.g. at UTM 674273 8453879). The sandstones are honey-brown weathering, well sorted rocks with calcite cement. Detrital muscovite flakes are aligned on bedding surfaces and detrital garnet grains are locally present. Bed thicknesses vary up to about $1 \mathrm{~m}$.

Basal boundary: The basal boundary represent an unconformity, and is recognised by the change from underlying upper Cretaceous marls of the Mifume Formation to overlying lower Cenozoic bioclastic limestones of the Alto Jingone Formation. 
Age: The rich fossil content in the limestones, including the nautiloid Hercoglossa denica suggest a Paleocene to Early Eocene age, while larger foraminifera in upper marls indicate an Early Eocene age (Civitelli, 1988).

Depositional environment: The Alto Jingone Formation was deposited adjacent to reefs in an open marine environment. The Palaeocene to Early Eocene bioclastic and coral reefs exposed from Pemba south to Simoco pass into laterally into apron debris and more distal carbonate muds and sands. In the northern outcrops around Quissanga, interbedded shallow marine carbonates, calcareous sands and muds are the dominant facies.

Remarks: The local gentle westward dips of bedding is attributed to faulting that may have been contemporaneous with sedimentation as the underlying and overlying beds are flat lying.

\section{Quissanga Formation}

Name: The carbonate-bearing lower Miocene succession comprising the present Quissanga Formation, first identified by Flores and Noseda (1961) has been referred to as the Sancul/Cogune Formation and corresponds to the "Quartz-arenites and larger foraminiferal marls" of Civitelli (1988). It is now named after the coastal town of Quissanga.

Type section: North of Quissanga at UTM 6614728625208.

Reference section: South of Pemba at UTM 6669088554347.

Thickness: The formation was estimated to be about $30 \mathrm{~m}$ thick by Civitelli and Mariani (1984) although sediments with the same Eocene-Oligocene age in the Mocimboa-1 Borehole are about $1405 \mathrm{~m}$ in thickness.

Distribution: There are a number of small coastal outcrops between Quissanga in the north to Ponta Ouissiquitxi in the south (Fig. 2).

Lithology: This formation comprises a lower sandstone unit overlain by reefoidal to micritic limestones. A distinctive white, well-sorted, medium-grained sandstone with a kaolinitic cement is exposed in the type section and is considered to form the lower part of the formation. The sandstone is fairly massive but appears to have a low dip below conglomeratic and micritic limestones considered to form the upper part of the Quissanga Formation. In the road north of Quissanga (UTM 661677 8625418), fine-grained micritic limestone clasts are set in a sandstone matrix and beds of more massive shelly micritic limestone have karstic weathered surfaces (Fig. 11a). 
Flaggy sandy limestones quarried south of Pemba in the reference section contain abundant worm burrows (Fig. 11b) in beds that are up to $50 \mathrm{~cm}$ in thickness. The abandoned Pemba Clay Quarry worked silt-grade mottled brown and pale grey clays (cut by calcite veinlets) underlying Mikindani Formation sand. The clays are about $30 \mathrm{~m}$ in total thickness.

In the extreme south-east there is an uppermost flat-topped rock pavement, up to $2 \mathrm{~m}$ in height, in and around the village of Simuco underlain by coral limestone. Previous mappers have referred to these rocks as part of the Quissanga Formation. Thinly bedded limestones locally weather to form a subdued karstic topography. Isolated corals adhere to sandstone exposures north of Simuco at UTM 6707748465139 (near the small village of Namuala). These corals may be part of the Quissanga Formation although this is not proven.

Basal boundary: The Quissanga Formation appears to lie unconformably on the Mifume Formation (Fig. 2).

Age: The formation is of middle Eocene to Oligocene age (Civitelli and Mariani, 1984; Civitelli, 1988). The lower part of the formation contains larger foraminifera (Nummulites spp. and Discocyclina sella of middle Eocene age. The upper part of the formation contains the Nummulites intermedius-Eulepidina assemblage of Oligocene age.

Depositional environment: The Quissanga Formation comprises shallow water, coastal sediments.

\section{Chinda Formation}

Name: The formation is named after the village of Chinda. It has not been distinguished previously, but was formerly mapped as part of the Quissirua/Repa (now Alto Jingone Formation).

Type section: Gully east of Chinda, south of the road to Mbau at UTM 6154788719064.

Reference section: Northern edge of the Rio Messalo floodplain at UTM 6387958709305. Thickness: The formation is estimated to be over $30 \mathrm{~m}$ thick (Civitelli and Mariani, 1984).

Distribution: The formation is exposed in a narrow E-W belt just north of Chinda. The formation extends northwards from Chinda into the Rio Sinheu valley where burrowed pale grey medium-grained kaolinitic sandstones lie below pebbly gravel.

Lithology: In the type section a partly quarried gully cuts through buff to very pale grey kaolinitic sandstone with pale kaolinitic mudstone clasts and small vugs. The sandstone is 
fine to medium grained, well cemented and contains some yellowish to red iron oxide stained infill between fine-grained sandstone clasts in a pelletoid texture (Fig. 12c). A carious weathered texture is common as are narrow burrows and there are rare lenses including quartz pebbles up to $1 \mathrm{~cm}$ long. Below this hard kaolinitic sandstone, mid-grey friable mediumgrained, friable sandstone forms a lower part of the formation. The beds are up to $80 \mathrm{~cm}$ in thickness; but in places thinly bedded or cross-bedded units occur.

The escarpment in the reference section reveals a c.30 m thick sequence of whitish, weakly cemented, poorly sorted, medium-grained pebbly sandstones containing numerous worm casts and burrows. The sandstones are matrix-supported with subrounded to angular quartz grains in a clay-rich matrix. Quartz pebbles are concentrated in beds mostly confined to the lower one-third of the section where they increase in size downwards, up to about $15 \mathrm{~cm}$ in diameter. Secondary replacement by kaolin is common.

At UTM 6125428724990 (Fig. 12a) by the main road south to Macomia, north of the Rio Nango, pale grey consolidated kaolinitic sandstone contains paler grey kaolinitic mudstone patches/clasts. A cutting in the scarp south of Chinda (UTM 614129 8719206) exposes pale grey well-cemented medium-grained kaolinitic sandstones with scattered quartz grains up to 1 mm across. Vugs in the sandstone are partly filled with white kaolin and some beds are bioturbated with numerous vertical voids. The kaolinitic sandstones pass down into fine and medium-grained sandstones and interbedded buff to off-white siltstones at UTM 614170 8719130 with burrowed medium-grained white sandstone below. In the hillside to the west cross-bedded coarse-grained sandstones crop out (Fig. 12b).

Basal boundary: The base of the formation is not exposed as it is covered by Pleistocene to Recent sands.

Age: The formation appears to be conformably overlain by the Mikindani Formation and it may be partly equivalent in age to the Mikindani Formation, although there is no direct fossil evidence.

Depositional environment: The formation comprises alluvial sediments deposited during Neogene uplift, partly as a lateral facies equivalent of the Mikindani Formation. The feldspar content appears to have been heavily altered in situ and the resulting kaolin redeposited during diagenesis in acidic groundwater.

\section{Mikindani Formation}


Name: Named after Mikindani in southern Tanzania by Bornhardt (1900) who referred to this unit as the Mikindani Beds. The type area is in Tanzania. Flores and Noseda (1961) described the equivalent reddish brown sandstones with subordinate conglomerates in Mozambique.

Type sections: (1) Lithified sediments: The northern cliffs of the Mocimboa da Praia inlet, between UTM 6485938747632 and 6475618748134 (Fig. 13d). (2) Upper poorly consolidated sand unit: The large quarry south of Pemba at UTM 6649618554723 where the worked faces are over $15 \mathrm{~m}$ in height (Fig. 13b).

Reference section: The deep ravine west of Palma (UTM 656568 8809766)

Thickness: The exposed thickness of the formation is up to $100 \mathrm{~m}$ (in the Mocimboa da Praia area) although about $675 \mathrm{~m}$ is recorded in the Mocimboa-1 Borehole.

Distribution: The Mikindani Formation is widely distributed throughout the onshore Rovuma Basin outcrop, and extensively covers the plateau east from Mueda to Mocimboa da Praia.

Lithology: From the scattered well-exposed sections, the formation can be subdivided into two parts: a lower sandstone unit with significant basal conglomerate beds overlying an unconformity, and an upper thicker, generally sandy section. In key localities such as the quarry north of the Governor's house at Nangade (UTM 573136 8775873), and cliffs about $20 \mathrm{~km}$ south of Nangade, the base of the Mikindani Formation is a distinctly pebbly conglomerate, in this case above a sharp unconformity overlying the Macomia Formation. However, south of Pemba, on the west side of the major quarry at UTM 06649618554723 , red-brown, burrow-mottled sandstone disconformably overlies grey marl and limestone of the Alto Jingone Formation. The basal conglomerates are partly sorted to well sorted with clasts of vein quartz, quartzite and kaolinitic mudstone. They are commonly stratified with beds rich in quartz pebbles as well as matrix (quartz grains with clay)-supported beds.

The sandstones are fairly massive and tend to lack bedding, mainly due to extensive reworking of the sediment by burrowing organisms (e.g. Thalassinoides), traces of which can be seen in well exposed sections (Fig. 13c). The burrows are infilled with pale grey sandy mudstone. Some of the sandstones are cross-bedded and pebbly sandstone in lags and channels cut down into medium-grained burrowed sandstone (Fig. 13a). Individual beds are up to about $1.50 \mathrm{~m}$ in thickness and commonly wavy. The sandstones are poorly sorted with angular to sub-rounded quartz grains, up to about $3 \mathrm{~mm}$ in diameter, supported in a clay matrix. Erratically distributed rounded vein-quartz pebbles are up to $4 \mathrm{~cm}$ in diameter. The sandstones commonly have a fine to very fine-grained sand component and iron oxides and clay minerals as weak cement. Elsewhere the cement is either clay and/or carbonate. Where the weak cement has weathered away, the outcrop is covered by residual sand or sandy soil, 
commonly up to several metres in thickness. In the upper sequences e.g. at (UTM 650650 8664986), a typical exposure comprises $2 \mathrm{~m}$ red to orange-brown, medium- and coarsegrained, poorly sorted sandstone overlying better consolidated red-purple coarse-grained to pebbly sandstone, which is mottled in zones of burrowing.

The northern cliffs in the type section for lithified strata are made up of red-brown and greybrown, burrow mottled, medium-grained sandstone with rootlet traces. Thin interbeds of grey silty mudstone and siltstone are present. Bedforms include low-angle, laterally accreted channels with clay plugs. Where not destroyed by bioturbation, primary small-scale bedforms in the lower beds include unidirectional cross-bedded sets, 5-10 cm thick, indicating palaeoflow towards the east and south-east and mudstone beds.

In the reference section to the west of Palma a deep ravine cuts a section down through 6-10 m of typically red-brown, poorly sorted, medium- and coarse-grained sandstone which generally lacks bedding, into a pale buff grey pebbly conglomerate, $1.1 \mathrm{~m}$ thick, with a sharp base. This conglomerate overlies interbedded red, grey and brown mottled, medium-grained pebbly sandstones, conglomerates and grey and olive-green kaolinitic mudstones. These beds are all considered to belong to the Mikindani Formation as they pass laterally westwards into red, and locally pale grey mottled, medium to coarse-grained sandstones with lenses of matrix-supported pebble conglomerate.

Mikindani Formation sandstones weather to residual reddish-brown sands with concentrations of white vein quartz pebbles scattered on present-day land surfaces. One example, in a major quarry (UTM 631730 8740356) near Mocimboa da Praia, exposes reddish-brown sands with major concentrations (mostly of vein quartz) pebbles that appear to infill channels. The pebbles are up to about $5 \mathrm{~cm}$ in diameter and they are locally imbricated (to the east). In the type section for the poorly consolidated red sands there is a strongly bioturbated facies which in extreme cases becomes structureless due to the intense reworking. The sands are over $15 \mathrm{~m}$ thick (Fig. 13b) and worm burrows are preserved only in the basal beds. Small irregular nodules of pedogenic carbonate in the sands are considered to be due to secondary hydrological circulation of groundwater.

Basal boundary: The lower boundary of the formation is marked by a basal conglomerate.

Age: No age-diagnostic fossils are so far found in the Mikindani Formation in the Rovuma Basin in Mozambique, but a general Miocene-Pliocene age can be assigned since it post-dates the Oligocene deposits of the uppermost Quissanga Formation. Assuming that the formation is genetically linked to the development of the Rovuma Deltaic Complex a Miocene age is likely for the bulk of the formation. 
Depositional environment: Bornhardt (1900) interpreted the Mikindani Formation as marine whilst Flores and Noseda (1960) interpreted the sediments as fluviatile/deltaic. We interpret the Mikindani Formation as shallow marine or estuarine with the upper unconsolidated red sands originating as offshore sand bars sourced from underlying sandstones. The ancient Rovuma River Delta is thought to have deposited much of the Mikindani Formation. Unidirectional cross bedding in the Mocimboa da Praia area indicates an east to east-southeast palaeoflow. The low angle channels down-cutting through interdistributary, bioturbated sandstones, and locally, with bi-directional cross-bedding, suggest a fluctuating fluvial to tidally influenced delta-top environment in the upper part of the formation.

\section{Geotectonic evolution of the Rovuma Basin}

It has already been established that the stratigraphical development of the Rovuma Basin is directly related to the 'progressive' break-up of south-western Gondwana and Cenozoic intracontinental tectonism associated with the East Africa Rift System (Salman and Abdulah, 1995; Nicholas et al. 2006, 2007). The following sequence of events is identified:

1. Late Carboniferous to Triassic intracratonic rifts in central and western northern Mozambique that were discordant to pre-existing structures in underlying bedrock (e.g. Key et al., 2007) are infilled by Karoo siliciclastic sediments. These early rifts remained intracontinental and were not associated with basaltic volcanicity in eastern Africa in contrast to the voluminous outpourings of Karoo flood basalts further south. Bounding faults to these early rifts trend NE-SW in northern Mozambique and are not followed by later faults that control the orientation of the Rovuma Basin.

2. Later (Triassic to early Jurassic) rifting close to, and parallel or sub-parallel with the ( N-S to NNW-SSE) suture along which eastern Africa subsequently separated from other components of south-western Gondwana produced a series of half grabens with up to $2.5 \mathrm{~km}$ of predominantly continental sediments. There are possible marine as well as continental sediments preserved in southern Tanzania. The relatively thin ( $100 \mathrm{~m}$ in thickness) sediments of the N'Gapa and Rio Mecole formations were deposited during this period in asymmetrical rifts that cut across structures in the underlying crystalline rocks. Palaeocurrent directions from the NW and NE confirm the intra-continental setting of the rifts.

3. The break-up of Gondwana during middle Jurassic times ( $165 \pm 10 \mathrm{Ma}$ ) due to active sea floor spreading (Reeves, 2003; Reeves et al., 2002; Jelsma et al., 2004) created marginal basins in the western part of the Indian Ocean along the eastern side of 
Africa. During this strongly transgressive period shallow marine sediments extended onto a platform of newly formed oceanic crust with a possible maximum thickness of about 3km. The development of eastern Africa's coastline commenced in the northfacing gulf offshore of present-day Somalia and north-eastern Kenya with lower Jurassic (Toarcian) sedimentation. However, in the southern, south-facing gulf sedimentation commenced in southern Tanzania during the middle Jurassic (associated with the start of dextral strike-slip movement along the Davie Ridge at about 165 Ma (that continued until about $118 \mathrm{Ma}$ ) and during lower Cretaceous (Aptian) times in northern Mozambique (Förster, 1975; Smelror et al., in press; this paper). This temporal development of the coastline confirms the 'scissors-like' opening of the two gulfs with a hinge/fulcrum in what is now northern Tanzania (Reeves 2003; Reeves et al., 2002). A Late Jurassic unconformity reflects a change to transform-controlled passive margin conditions as Madagascar moved southwards relative to mainland Africa (Raillard, 1990). The coarse basin margin sediments above the unconformity are now referred to as the Macomia Formation and the marine sediments are referred to as the Pemba Formation. Intermittent faulting accompanied sedimentation. The NNW-SSE fault system that defines the western margin of the Rovuma Basin cuts across the ENE-WSW structural grain of the underlying Precambrian crystalline basement. This is because the NNW- SSE faulting reflects a global stress system initiated in Mesozoic times. However, a number of ENE-WSW transfer faults have been identified in the offshore part of the Rovuma Basin and these could represent reactivated Precambrian ductile shears. Contemporaneous uplift of the interior of southern and central-eastern Africa was accompanied by enhanced weathering that in turn led to an increase in sedimentation into the Rovuma Basin.

4. Stabilization of the East Africa continental margin occurred between 118 and $35 \mathrm{Ma}$ (Salman and Abdula, 1995). The Late Cretaceous was typified by a widespread transgression in eastern Africa with uniform marls/clays (including the Mifume Formation) deposited along the whole continental margin and prograding onto the continental slope. Borehole Mocimboa-1 penetrated 1380m into the marls. Shallow water carbonate sediments (of the Alto Jingone and Quissanga formations) were deposited during the Paleocene and Eocene with a reefal facies along the outer edge of the shelf. There were periods of relatively low sea levels to create low-stand submarine fans, one of which provided the target for Mocimboa-1. From about $93 \mathrm{Ma}$ when Madagascar started to separate from India to ddevelop the Mascarene Basin, the 
Rovuma Basin formed part of a passive margin with little evidence for faultcontrolled sedimentation (Kent et al., 1971)

5. Deltaic Progradation caused by renewed rifting along the East African Rift System commenced at about 35Ma and has continued intermittently to the present day, mostly with deposition of marine and deltaic sediments (of the Mikindani and possibly Chinda formations). Uplift/doming of Africa in the Oligocene that preceded the formation of the East African Rift initiated the Rovuma River Delta System associated with a marine regression. A Miocene transgression led to shallow water marine sedimentation during progradation of the delta (contemporaneous with riftrelated onshore sedimentation in the East African Rift System). Quaternary uplift led to the present day outcrop of the Miocene sediments on the mainland of $\mathrm{NE}$ Mozambique. The present coastline of northern Mozambique remains fault controlled with intermittent movement on N-S faults resulting in earthquakes. Active vertical faulting accompanied sedimentation throughout the Cenozoic (Kent et al., 1971).

Tectonic influence on the Rovuma Basin

Climate changes recorded in the sediments

\section{Conclusions}

Nine lithostratigraphic formations are formalised in the onshore part of the Rovuma Basin in northern Mozambique. The new data on the sediments and their respective absolute ages confirms previous, mainly geophysical accounts of the development of the eastern coastline of Africa over the last 200 million years of fragmentation of south-western Gondwana to create a separate African continent. Although the eastern coastline of Africa is regarded as a 'passive' margin, it is clear from the preserved sedimentary record in the onshore part of the Rovuma Basin, that faulting, mostly with vertical movements, has always remained a major control on sedimentation. Evidence for faulting is given by rapid lateral facies and thickness changes as well as by common convoluted bedding structures. The Mocimboa- 1 Borehole shows the rapid eastward increase in thickness of the post-Pemba Formation sediments from less than several hundred metres to about $3000 \mathrm{~m}$ over horizontal distances of less than 30 $\mathrm{km}$. The NNW-SSE bounding faults to the Rovuma Basin are the result of a global stress system that commenced in Mesozoic times and led to the development of $\mathrm{N}$-facing and Sfacing gulfs along the eastern margin of what became the African continent. The fulcrum point separating the two gulfs was in what is presently northern coastal Tanzania. Complete separation of Africa from the rest of Gondwana occurred during the Cretaceous when sea 
water entered the fulcrum area. This coincided with an increase in sedimentation into coastal parts of the newly formed African continent. Thus the greatest accumulation of sediments occurred during Cretaceous times with about $3000 \mathrm{~m}$ of sediment recorded in the Pemba Formation ( 155-112 Ma), about 500m in the Macomia Formation ( 125-100 Ma) and up to about $810 \mathrm{~m}$ in the Mifume Formation ( 100-65Ma). The subsequent slow down in sedimentation during Cenozoic times coincides with an order of magnitude reduction in erosion of the southern Africa's interior (Tinker, 2005;de Wit, 2007; Kounov et al., 2007).

Early (pre-drift) fluviatile sedimentation (Rio Mecole and N'Gapa formations) was confined to isolated half-grabens with proximal sediments derived from underlying crystalline bedrock. This was followed by high-energy fluviatile sedimentation (Macomia Formation) on the landward side of the developing coastline and offshore deltaic to shallow shelf sedimentation (Pemba Formation). Coastal progradation led to open marine and reef sedimentation (Mifume and Alto Jingone formations). The Quissanga Formation is made up of shallow water coastal sediments, and the deltaic Mikindani Formation (and possibly the alluvial fan Chinda Formation) sediments are a response to uplift of Africa during the development of the East African Rift System. The development of a thick, eastward-prograding sedimentary wedge offshore of the Rovuma River, as well as the coastal sediments of the Mikindani Formation, since about 34 Ma BP can be attributed to the onset of rifting and uplift associated with the development of the East African Rift System. The linear N-S shape of the present coastline of northern Mozambique reflects ongoing faulting. Reactivated ENE-WSW ductile shears in the underlying crystalline rocks of northern Mozambique may control the location of transfer brittle faults identified in the offshore part of the Rovuma Basin.

\section{Acknowledgements}

Drs Key and Smith publish with the permission of the Chief Executive of BGS (NERC). Professor Colin Reeves is thanked for confirming the temporal framework for the various stages in the separation of Africa from the rest of eastern Gondwana.

\section{References}

Afonsky, M., Lomtev, V., Abdula, I., 1990. Rovuma Basin. Report on the fieldwork conducted in Pemba and Nacala areas. Empresa Nacionale de Hidrocarbonetos de Mozambique (ENH) in-house report, November 1990.

Aitken, W.G. 1960. Makonde Beds. Pp 59-60 in Lexique Stratigraphique International, 4 (8c). 171p. 
Bornhardt, W., 1900. Zur Oberflächengestaltung und Geologie Deutsch Ost-Afrikas, Bd. VIII. Dietrich-Reimer, Berlin.

Civitelli, G., 1988. The Meso-Cenozoic sedimentary sequence of the Cabo Delago Province, Mozambique. Journal of African Earth Sciences, 7, 629-639.

Civitelli, G. and Mariani, F. 1984. Estudo geológica do sedimentary da Provincia de Cabo Delgado finalizado a pesquisa de gerso. Rel. ined. BGI, ING, Maputo.

Collins, S. 2003. Mega-tectonic, structural and palaeogeographic framework of East Africa. In: First conference on the petroleum potential and investment opportunities in East Africa EAPC '05, Nairobi, Kenya. Conference Report (Abstracts), East African Community Secretariat, Arusha, p.113.

Daniels, C.H., von Gramann, F., Jaritz, W., Kemper, E., Koch, W., 1977. Zum Vorkommen von Sedimentgesteinen des Mesozoikums und des Tertiärs im Küstengebiet von Nordmozambique. Geologiisches Jahrbuch, 167-172.

de Wit, M. 2007. The Kalahari Epeirogeny and climate change: differentiating cause and effect from core to space. South African Journal of Geology, 110, 367-392.

Engvik, A.K., Tveten, E., Bingen, B., Viola, G., Erambert, M., Feito, P. and De Azavedo, S. 2007. P-T-t- evolution and textural evidence for decompression of Pan-African high-pressure granulites, Lurio Belt, north-eastern Mozambique. Journal of Metamorphic Geology, 1-18.

Flores, G.M., 1960. Reconnaissance of Porto Amelia, Cabo Delgado area. Rel. ined. Mozambique Gulf Oil Company. ING, Maputo.

Flores, G.M. 1973. The Cretaceous and Tertiary sedimentary basins of Mozambique and Zululand. In: Blant, G.T. (Ed.), Sedimentary Basins of the African Coasts. Part II. Association of African Geological Survey, Paris, 81-111.

Flores, G. and Noseda, C. 1960. Reconnaissance of Porto Amelia, Cabo Delgado area. Rel. ined. Mozambique Gulf Oil Company. ING, Maputo.

Flores, G. and Noseda, C. 1961. The geology of the Rovuma area. Unpublished Report, Mozambique Gulf Oil Company. ING, Maputo.

Förster, R. 1975. The geological history of the sedimentary basin of southern Mozambique, and some aspects of the origin of the Mozambique Channel. Palaeogeography, Palaeoclimatology, Palaeoecology, 17, 267-287. 
Hancox, P.J., Brandt, B., Edwards, H., 2002. Sequence stratigraphic analysis of the Early Cretaceous Maconde Formation (Rovuma basin), northern Mozambique. Journal of African Earth Sciences, 34, 291-297.

Jelsma, H.A., de Wit, M.J., Thiart, C., Dirks, P.H.G.M., Viola, G., Basson, I.J. and Anckar, E. 2004. Preferential distribution along transcontinental corridors of kimberlites and related rocks of Southern Africa. South African Journal of Geology, 107, 301-324.

Kent, P.E., Hunt, J.A. and Johnstone, D.W. 1971. The geology and geophysics of Coastal Tanzania. Institute of Geological Sciences Geophysical Paper No. 6, HMSO, London.

Key, R M., Smith, R A., Thornses, T., Smelror, M., Saether, O M., Solli, A., Sandstad, J S., Bjerkgård, T., Zandamela, E B., Powell, J H. 2006. Rovuma Basin: Onshore geology in northern Mozambique. Abstract CAG 21, 232-233, Maputo, June 2006.

Kounov, A., Niedermann, S., de Wit, M.J., Viola, G, Andreoli, M. and Erzinger, J. 2007. Present day denudation rates bearing on erosion processes along selected west- and southfacing sections of the South African Great escarpment and its interior derived from in situ produced cosmogenic 3He and 21 Ne. South African Journal of Geology, 110, 235-248..

Lonropet SARL. 2000. Rovuma Basin, Mozambique. Fieldwork Interpretation and Analyses Report. The Petroleum Geology and Hydrocarbon Prospectivity of Mozambique '2000'. Confidential Report, ING, Maputo, Mozambique.

Mariani, F., Castelet, Y. and Ballara, G. 1984. Relatorio sobre a pesquisa de calcarios para cal em Pemba (Provincia de cabo Delgado). Rel. ined. BGI, ING, Maputo.

Moura, A.R. 1974. Noticia expletive da parte sedimentary do grau quadrado, 14-40. ING, Maputo.

Nicholas, C.J., Pearson, P.N., Bown, P.R., Jones, T.D., Huber, B.T., Karega, A., Lees, J.A., McMillan, I.K., O’Halloran, A., Singano, J.M. and Wade, B.S. 2006. Stratigraphy and sedimentology of the upper Cretaceous to Paleogene Kilwa Group, southern coastal Tanzania. Journal of African Earth Sciences, 45, 431-466.

Nicholas, C.J., Pearson, P.N., McMillan, I.K., Ditchfield, P.W. and Singano, J.M. 2007. Structural evolution of southern coastal Tanzania since the Jurassic. Journal of African Earth Sciences, 48, 273-297. 
Pearson, P.N., Nicholas, C.J., Singano, J.M., Brown, P.R., Coxall, H.K., van Dongen, B.E., Huber, B.T., Karega, A., Lees, J.A., Msaky, E., Pancost, R.D., Pearson, M. and Roberts, A.P. 2004. Paleogene and Cretaceous sediment cores from the Kilwa and Lindi areas of coastal Tanzania: Tanzania Drilling Project Sites 1-5. Journal of African Earth Sciences, 39, 25-62.

Pearson, P.N., Nicholas, C.J., Singano, J.M., Brown, P.R., Coxall, H.K., van Dongen, B.E., Huber, B.T., Karega, A., Lees, J.A., MacCloud, K., McMillan, I.K., Pancost, R.D., Pearson, M. and Msaky, E. 2006. Further Paleogene and Cretaceous sediment cores from the Kilwa area of coastal Tanzania: Tanzania Drilling Project Sites 6-10. Journal of African Earth Sciences, 45, 279-317.

Pinna, P. \& Marteau, P., 1987. Carta geologica de Moçambique, 1:1000000 scale, with explanatory notes. Instituto Naçional de Geologica, Maputo, Maputo.

Raillard, S.1990. Les Marges de l'Afrique de l'Est et les zones de fractures associees; Chaine Davie et Ride du Mozambique. Translated Title: East African continental margins and associated fracture zones; Davie and Mozambique ridges. Universite de Paris VI. Paris, France. Pages: 272.

Reeves, C.V., 2003. East Africa and Western India: Passive margins from the evolution of a complex ocean. Poster presentation (5 posters), American Association of Petroleum Geologists meeting, Barcelona, September 2003.

Reeves, C.V., Sahu, B.K., and de Wit, M.J., 2002. A re-examination of the paleo-position of Africa's eastern neighbours in Gondwana. Journal of African Earth Sciences. Vol. 34, pp 101108.

Salman, G. and Abdula, I. 1995. Development of the Mozambique and Ruvuma sedimentary basins, offshore Mozambique. Sedimentary Geology, 96, 7-41.

Smelror, M., Key, R M., Daudi, E. and Njange, F. 2006a. Frontier with high expectations. GEO ExPro, March 2006, 14-18.

Smelror, M., Key, R M., Smith, R A. Thornses, T. Saether, O M. Zandamela, E B. and Powell, J H. 2006b. Revised lithostratigraphy of the onshore Rovuma Basin, northern Mozambique. Abstract CAG 21, 248-250, Maputo, June 2006.

Smelror, M., Key, R.M., Njange, F, Smith, R.A. in press. Palynostratigraphy of the Late Jurassic and Early Cretaceous of the onshore Rovuma Basin, northern Mozambique. Palynology. 
Tinker, J. 2005. Using apatite fission track thermochronology and offshore sedimentary volumes to test the balance between denudation (onshore) and deposition (offshore) since Gondwana break-up. Unpublished PhD Thesi., University of Cape Town, South Africa, 243pp.

\section{Figures:}

Figure 1: Location map of the Rovuma Basin (modified from Engvik et al., 2007).

Figure 2: Simplified bedrock map of the Rovuma Basin in northern Mozambique

Figure 3: DTM image of northern coastal Mozambique showing the fault control along the western edge of the Rovuma Basin.

Figure 4: Revised lithostratigraphic scheme for the onshore Rovuma Basin, northern Mozambique (excludes the Rio Mecole and N'gapa formations that are confined to separate fault-bounded basins to the west of the Rovuma Basin).

Figure 5: Rio Mecole Formation photographs: (a) Outcrop of the Rio Mecole Formation along the main road from Mueda to Pemba (UTM 37S 06270 8549). Here the formation comprises a fining-upwards sequence of pebbly sandstone, locally with low-angel cross-beds (Photo RK164). (b) Basal breccia of the Rio Mecole Formation, with a block of granitic gneiss $>2 \mathrm{~m}$ in diameter (Photo TT-0082a).

Figure 6. A pebbly cross-bedded sandstone of the N'Gapa Formation with forests dipping $25^{\circ}$ to $24^{\circ} \mathrm{NE}$, at UTM 37S 531864 8750230. (Photo: RS09).

Figure 7. Macomia Formation photographs: (a) Heavy mineral seams in arkosic sandstones close to the top of the Macomia Formation. Quarry at Nangade at UTM 37S 0573005 8776102 (Photo RK79b). (b) Sandstone interbeds containing cobbles and boulders of reddish, medium- to coarse-grained sandstone up to $2 \mathrm{~m}$ in length. West of Macomia at UTM 37S 611925864710 (photo RS299). (c) Cave exposure of multi-storey trough cross-bedded, arkosic sandstone units between 0.4 and 2 m in thickness. At UTM 37S 6090718647724 (photo RS300a).

Figure 8. Pemba Formation photographs. (a) Buff-grey to off-white, shelly bioclastic limestone intercalations near the Bilibiza Agricultural College at UTM 37S 6374098611220 (Photo RS229a). (b) Crab burrow in interbedded mudstones and sandstones of the Pemba Formation at UTM 06539308547859 (Photo RK197c). (c) Convoluted bedding in sandstones of the Pemba formation at UTM 06473398525038 (Photo RK270a). (d)- Turbidite section in the upper part of the Pemba formation at UTM 06597748497419 (Photo RK373b). (e) Fining-upwards siltstones exposed in a small quarry at UTM 06546648554769 in the middle part of the Pemba Formation (Photo RK298). 
Figure 9. Mifume Formation strongly bioturbated marls full of worm burrows at UTM 06610488553172 (Photo RK177). Field of view approximately $15 \mathrm{~cm}$ in width.

Figure 10. Alto Jingone Formation photographs. (a) Typical section through bedded marls of the Alto Jingone Formation exposed in a small quarry on the outskirts of Pemba at UTM 37S 0664690 8554383. (Photo RK175). (b) Off-white to cream coloured, partly sparry, mediumgrained limestone containing Nummulites and scattered yellow-brown mudstone clasts and small broken shell fragments at UTM 37S 643569 8663302. (Photo RS180). Field of view approximately $100 \mathrm{~cm}$ in width. (c) Interbedded fine-grained, sparry cream limestones and fine-grained calcareous sandstones with numerous Nummulites on bedding planes with horizontal sand-filled worm burrows at UTM 37S 644147 8663468. (Photo RS330). (d) Brecciated coral surface of the Alto Jingone Formation at UTM 37S 06706118467567. (Photo RK400).

Figure 11. Quissanga Formation photographs. (a) Exposure with micritic limestone clasts supported in a sandstone matrix at UTM 37S 661677 8625418. (Photo RS286). (b) Interbedded laminated sandstones and limestones with linear worm burrows in excess of $10 \mathrm{~cm}$ in length exposed in a small quarry at UTM 37S 0666908 8554347, south of Pemba. (Photo RK200a).

Figure 12. Chinda Formation photographs. (a) Weakly bedded, kaolinitic sandstones exposed in a road cut north of the Rio Nango at UTM 37S 612542 8724990. (Photo RS70b). (b). Cross-bedded, coarse-grained sandstone with weathered out pebbles exposed in hills west of UTM 37S 614170 8719130. (Photo RS440). (c) Kaolinitic, pale grey sandstone with pelletoid texture and kaolinitic mudstone clasts exposed in a small quarry east of Chinda at UTM 37S 615478 8719064. (Photo RS362).

Figure 13. Mikindani Formation photographs. (a) Pale pink, burrowed, fine-grained sandstone bed underlying pink-brown conglomeratic sandstone that also infills a groove into the top of the sandstone bed at UTM 37S 650-277 8664728. (Photo RS338). (b) Red sand facies of the Mikindani Formation in its type area south of Pemba at UTM 37S 06649618554723. The sands are completely structureless due to extreme bioturbation (Photo RK174b). (c) Base of the Mikindani Formation with worm burrows in sandstone overlying marls of the Quissanga Formation at UTM 37S 664961 8554723. (Photo RK174y). (d) Cliffs of interbedded crossbedded, channelled sandstones (including unidirectional cross-bedded units) and mudstones north of Mocimboa da Praia near UTM 0648593 8747632. (Photo JHP274a).

\section{Table:}

1. A comparison of stratigraphical terminology applied to the Rovuma Basin in southern coastal Tanzania (after Nicholas et al., 2006) and northern coastal Mozambique (this paper). 
2. The post-Karoo geotectonic development of the Rovuma Basin as recorded in the nine lithostratigraphic formations recognised in its present-day onshore component in northern Mozambique. 